\title{
Effect of Fissile Isotope Burnup on Criticality Safety for Stored Disintegrated Fuel Rods
}
S. W. Heaberlin
G. P. Selby

September 1978

Prepared for the U.S. Department of Energy under Contract EY-76-C-06-1830

Pacific Northwest Laboratory Operated for the U.S. Department of Energy by 


\title{
NOTICE
}

This report was prepared as an account of work sponsored by the United Siates Covernment. Neicher the Unired States nor the Department of Enetgy, nor any of their employees, tor any of ineir contractors, subcontractors. or their empioyees, makes any warranty. express or implied, is asstimes any legal liabilit; or responsibility for the accuracy, compieteness or usefulness of any intonnation, apparatus, product or proces5 disclosed, or represents that its use would not ialringa privaleiy owned rights.

The views, opinions and conclusions contained in this report are those of the cantractor and so not necessarily represent those of the Lnited States Covernment or the United States Deoartment of Energy.

\author{
PACIFIC NORTHWEST LABORATORY \\ operated by \\ BATTELLE \\ tor the \\ UNITED STATES OLPARTMENT OF ENERGY \\ Under Contract EX-76-C-05-7830
}

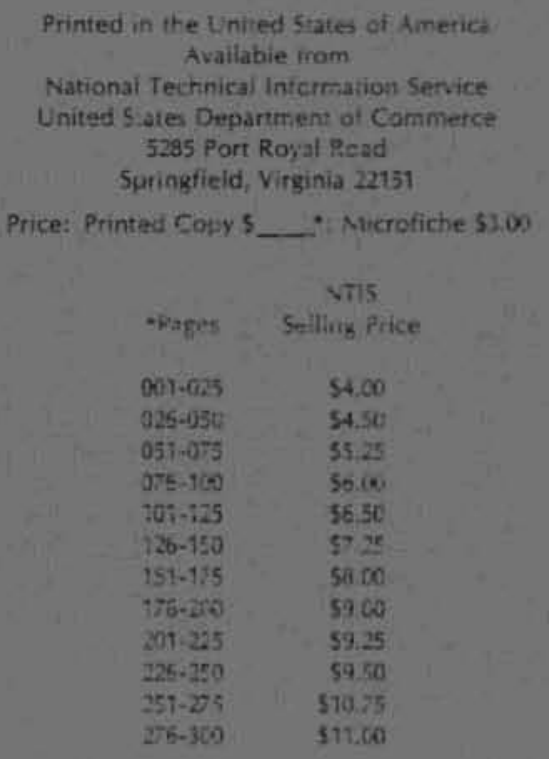


33679000491383

EFFECT OF FISSILE ISOTOPE BURNUP ON CRITICALITY SAFETY FOR STORED DISINTEGRATED FUEL RODS

S. W. Heaberl in

G. P. Selby

September 1978

Prepared for

the U.S. Department of Energy under Contract EY-76-C-06-1830

Pacific Northwest Laboratory

Richland, Washington 99352 



\section{TABLE OF CONTENTS}

1.0 INTRODUCTION .

2.0 SUMMARY . . . . . . . . . . . . . . . . . . . . . . . 2

3.0 METHODS . . . . . . . . . . . . . . . . . . . . . . 3

4.0 RESULTS AND CONCLUSIONS . . . . . . . . . . . . . . . . . . 4

REFERENCES . . . . . . . . . . . . . . . . . . . . . . . . . . . . 9

APPENDIX A: MATERIAL COMPOSITIONS ASSUMED IN REACTIVITY

CALCULATIONS . . . . . . . . . . . . . . . . A-1

\section{$\underline{\text { LIST OF FIGURES }}$}

FIGURE 1 Reactivity of Reference 13-Inch Canister With Disintegrated Fuel Solution . . . . . . . . . . . . . . . . 5

FIGURE 2 Critical ( $k_{\text {eff }}=1.0$ ) Cylinder Diameter With Disintegrated Fuel Solutionf................. . . 6 $\begin{aligned} \text { FIGURE } 3 & K_{\text {eff }}=0.95 \text { Cylinder Diameter With Disintegrated Fuel } \\ & \text { Sofution................. }\end{aligned}$ 



\subsection{INTRODUCTION}

Recent changes in U.S. domestic nuclear energy policies have deferred indefinitely the reprocessing of spent nuclear fue1. The Spent Fuel Handling and Packaging program has as its goal the design and construction of a facility to store the increasing inventory of spent fuel. One item to be included in design consideration is criticality safety. Our recent study (1) describing criticality safety comparisons for seven spent fuel storage facility concepts pointed out a major safety problem in the case of disintegrated rods. Such disintegration could occur if the fuel material is exposed to air at elevated temperatures. If the resulting powder is combined with water in the reference 13-in. diameter PWR canister, a criticality could result. One of the items indicated in the earlier study as requiring further investigation is the effect of fissile isotope burnup. It is the purpose of this study to provide some preliminary insight as to how effective taking credit for fissile isotope burnup is in reducing the criticality safety problem.

Severai important qualifications and reservations must be stated regarding this study.

- In 1 icensing of spent fuel storage facilities, credit for burnup is normally not allowed.

- The level of burnup of any given assembly would be difficult to determine and even more difficult to guarantee.

- The calculations given in this study are based on estimates of isotopic ratios at various levels of burnup. Actual isotopic ratio could differ sianificantly.

- The calculations treat the fuel as mixed oxide containing only the fissionable isotopes $\left({ }^{235} \mathrm{U},{ }^{238} \mathrm{U},{ }^{238} \mathrm{Pu},{ }^{239} \mathrm{Pu},{ }^{240} \mathrm{Pu},{ }^{241} \mathrm{Pu}, 242 \mathrm{Pu}\right)$. This is conservative since other uranium isotopes which act as poisons and strong fission product poisons are neglected.

This study provides a conservative view of the effect on criticality safety of canisters containing disintegrated rods, if the licensing bodies would allow credit for burnup and if burnup levels could be verified. 


\subsection{SUMMARY}

In previous criticality safety work for this program, (1) a serious problem was encountered. If the fuel rods were to disintegrate and water added, a criticality could occur in a 13-in. PWR canister. Calculations indicating this were made assuming fresh fuel enriched to $3.5 \mathrm{wt} \%{ }^{235} \mathrm{U}$. This is a common assumption in spent fuel storage criticality safety analyses. An obvious question is, "If credit could be taken for burnup, could this indicate a subcritical condition?" In attempting to answer this question, a series of calculations were performed. A set of isotopic concentrations were generated for 5,000,10,000,15,000 and 20,000 MWD/MTU burnup levels with the computer code ORIGEN. (2) Neutron cross sections for the optimally moderated mixtures of the fissionable oxides at each burnup level were prepared with the EGGNIT-II ${ }^{(3)}$ code. The HFN ${ }^{(4)}$ code was used to determine the reactivity at the 13-in. canister diameter. The diameter for criticality $\left(k_{\text {eff }}=1.0\right)$ and 'subcritical' $\left(k_{\text {eff }}=0.95\right)$ were also calculated. Four reflector materials, water, concrete and two types of soil, were considered.

The results of the study indicate that, for the conditions assumed, allowing credit for fissile isotope burnup does not completely remove the concern for criticality safety in the event of rod disintegration. Reactivities which are 'subcritical' $\left(k_{\text {eff }}=0.95\right)$ would not occur for three of the four reflector materials at even the 20,000 MND/MTU burnup level in the 13-in. canister. The water reflected canister would achieve the $k_{\text {eff }}=0.95$ level near 18,000 MWD/MTU. A smaller canister could be postulated. If a quarter inch gap is allowed, a Westinghouse $17 \times 17$ PWR assembly requires a 12-1/4 inch diameter canister. For such a canister with water reflection the 'subcritical' ( $k_{\text {eff }}=0.95$ ) level would be reached near 15,000 MWD/MTU. The soil reflected canisters would reach this level between 18,000 and 19,000 MWD/MTU. Considering the difficulties in taking credit for burnup, such modest gains in apparent safety are not encouraging. This situation might be improved, however, if credit were al so taken for neutron absorption by fission product poisons produced during burnup.

It is strongly recommended that other approaches to a solution of the criticality safety problem be considered. The prerequisites for a 
criticality potential are rod disintegration and water intrusion. If rod disintegration cannot be prevented, then steps to deny the water entry to the fuel are needed. Enhanced canister integrity or a solid stabijizer medium are possible methods of achieving this. Other possible solutions could include alternative canister shapes, or reduced fuel per canister (less than one assembly). Addition of neutron poisons is also a possibility but a potential requirement for periodic inspections of the poisons could invalidate the criterion of a passive storage system.

\subsection{METHODS}

Fuel exposures from 0 to 20,000 MWD/MTU were included in this study. Higher levels of exposure are possible in today's LWR reactors, but it is reasonable to expect a spent fuel storage facility to receive fuel with 20,000 MWD/MTU burnup or less. For criticality safety, the lower the burnup the greater the reactivity. For this reason only the conservatively lower exposures were considered. The isotopic concentrations were generated with the ORIGEN ${ }^{(2)}$ computer code which models isotope generation and depletion in "a nuclear reactor. A constant power level of $30 \mathrm{MW} / \mathrm{MTU}$ was assumed with $3.5 \mathrm{wt} \%{ }^{235} \mathrm{U}$ as an initial enrichment. The isotopic concentrations were then edited after the appropriate burnup periods. For instance, the 15,000 MWD/MTU exposure concentrations were those calculated for 500 days at the constant $30 \mathrm{MW} / \mathrm{MTU}$ leve1. The isotopic concentrations for $0,5,000$, $10,000,15,000$ and 20,000 MWD/MTU. were determined. No correction was made for out of reactor time. However, with the exception of ${ }^{241} \mathrm{Pu}$, the decay times are very long in comparison to the postulated facility mission time of 25-100 years. The possible errors due to the ${ }^{241} \mathrm{Pu}$ decay are not considered to be significant.

The fuel form for the disintegrated rods was assumed to be the fissionable isotopes as oxides mixed with water. The fissionable isotopes are ${ }^{235} \mathrm{U},{ }^{238} \mathrm{U},{ }^{238} \mathrm{Pu},{ }^{239} \mathrm{Pu},{ }^{240} \mathrm{Pu}$, and ${ }^{242} \mathrm{Pu}$. Other uranium isotopes which act as neutron poisons are neglected. More significantly, the fission product poisons are also neglected. Inclusion of fission products could reduce the reactivity considerably. However, precise characterization of 
fission products of any given exposure history is a difficult matter. Attempting to justify an average or representative fission product model for the range of exposed fuel which may enter the facility would be extremely difficult. These factors lead to the conservative approach described above for use in this preliminary study.

For each burnup level the optimum degree of water moderation is determined with the EGGNIT-II ${ }^{(3)}$ code using ENDF/B-IV cross section data. The isotope number densities for the optimum solutions are listed in Appendix $A$. The EGGNIT-II code was used to generate 18 energy group cross sections for $\mathrm{HFN}^{(4)}$ which is a one dimensional diffusion theory code. HFN was used to calculate reactivity, in the form of the effective multiplication constant $k_{\text {eff }}$, for a 13-in. diameter reference canister. Searches were performed to find the cylinder diameter for two given reactivity levels. The two levels were critical ( $k_{\text {eff }}=1.0$ ) and $k_{\text {eff }}=0.95$, which is often used as an adequately subcritical level. All the calculations assume an infinitely long cylinder. In the cases considered here, the length to diameter ratios are greater than ten indicating that the assumption of infinite length introduces insignificant error.

In use, the spent fuel canister will be surrounded by some shielding material or have the possibility of being surrounded by water. These surrounding materials would reflect neutrons back into the fuel material. Four reflectors were considered: water, concrete (Type 04) ${ }^{(5)}$ and Hanford soil, ${ }^{(6)}$ with either $30 \mathrm{v} / 0$ or $40 \mathrm{v} / 0$ water content.

\subsection{RESULTS AND CONCLUSIONS}

The results of the calculations described in the preceding section are shown in Figures 1,2 and 3 . Figure 1 gives the reactivity of a 13-in. diameter cylinder of optimally moderated fissionable oxide solution with the various reflectors as a function of burnup. Criticality occurs below $10,000 \mathrm{MWD} / \mathrm{MTU}$ for the water reflected case, near 14,000 MWD/MTU for the soils and roughty at 15,000 MWD/MTU for the concrete. 


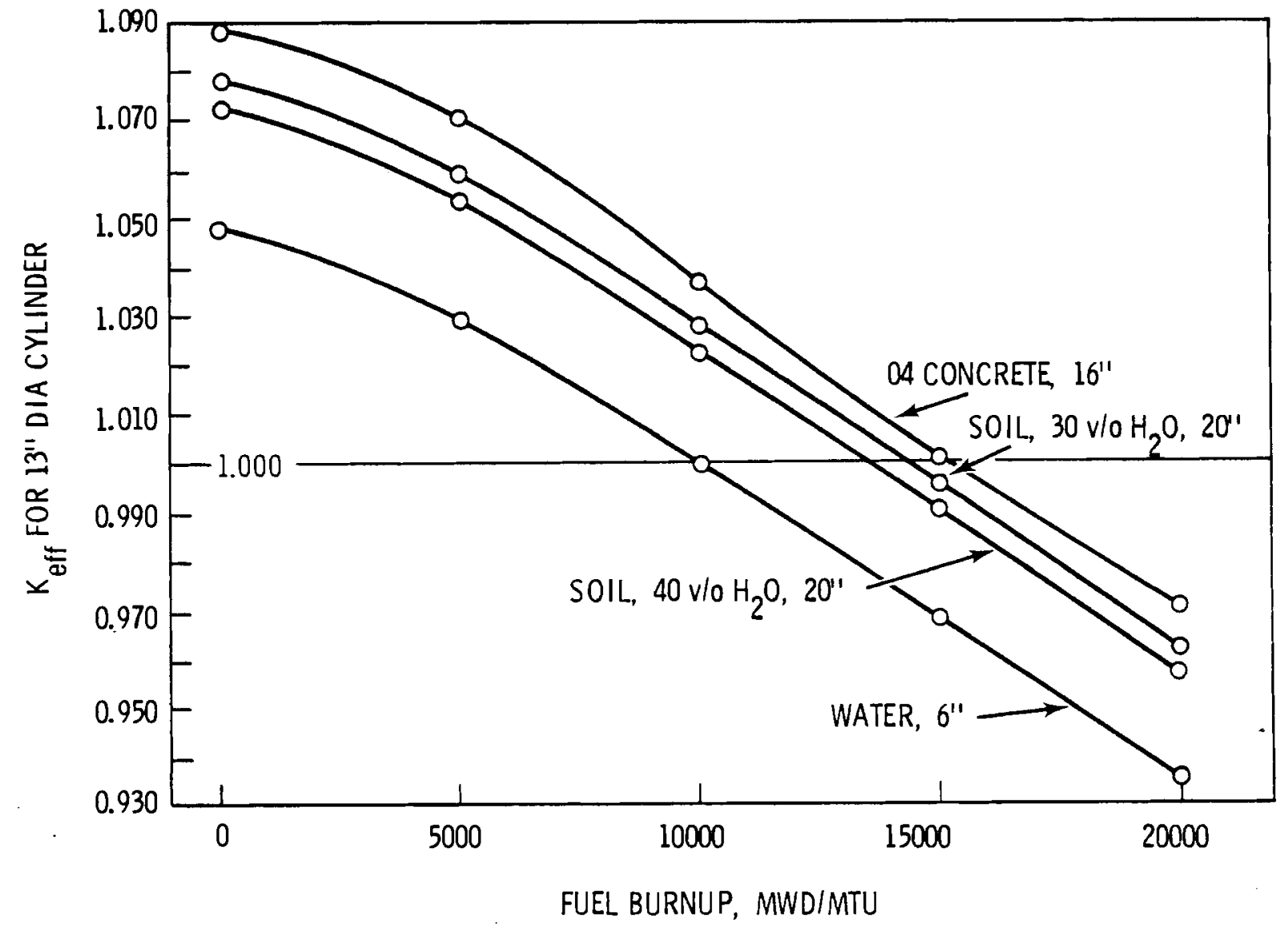

FIGURE 1. Reactivity of Reference 13-Inch Canister With Disintegrated Fuel Solution

One method of improving criticality safety would be to reduce the canister size. A Westinghouse $17 \times 17$ assembly requires a 12-1/4 in. diameter canister if a $1 / 4-i n$. gap is allowed. Figure 2 indicates that such a cylinder would be critical at exposure levels less than 12,500 MWD/MTU. Figure 3 shows the cylinder diameter which gives the subcritical $k_{\text {eff }}=0.95$ level of reactivity. This is more restrictive than the criticality $\left(k_{\text {eff }}=1.0\right)$ cylinder diameter shown in Figure 2, but demonstrates the reduction in size to reach 'safe' diameters. The 12-1/4 water reflected cylinder requires a burnup of almost 15,000 MWD/MTU to reduce the reactivity 


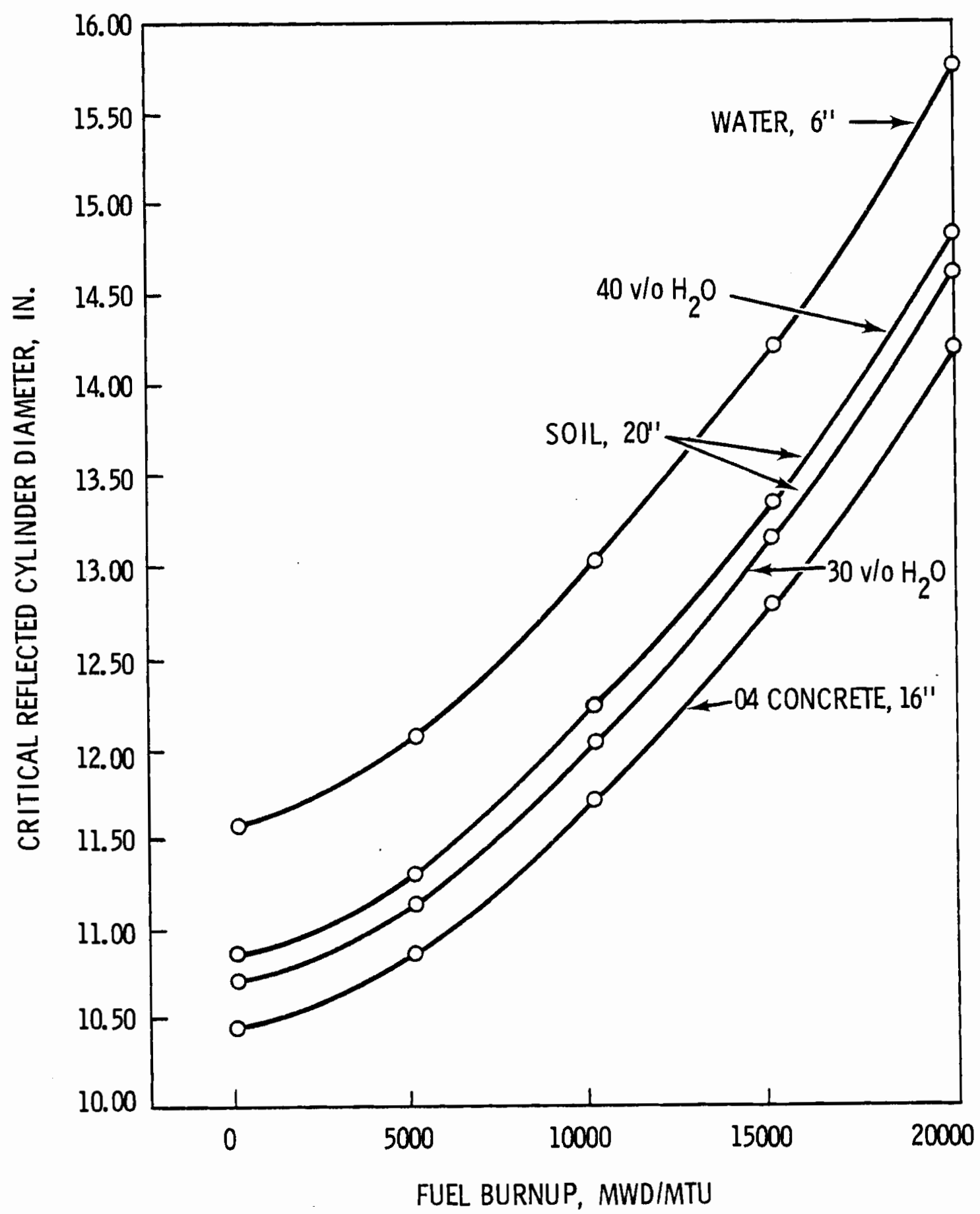

FIGURE 2. Critical ( $\left.k_{\text {eff }}=1.0\right)$ Cylinder Diameter With Disintegrated Fuel Solution 


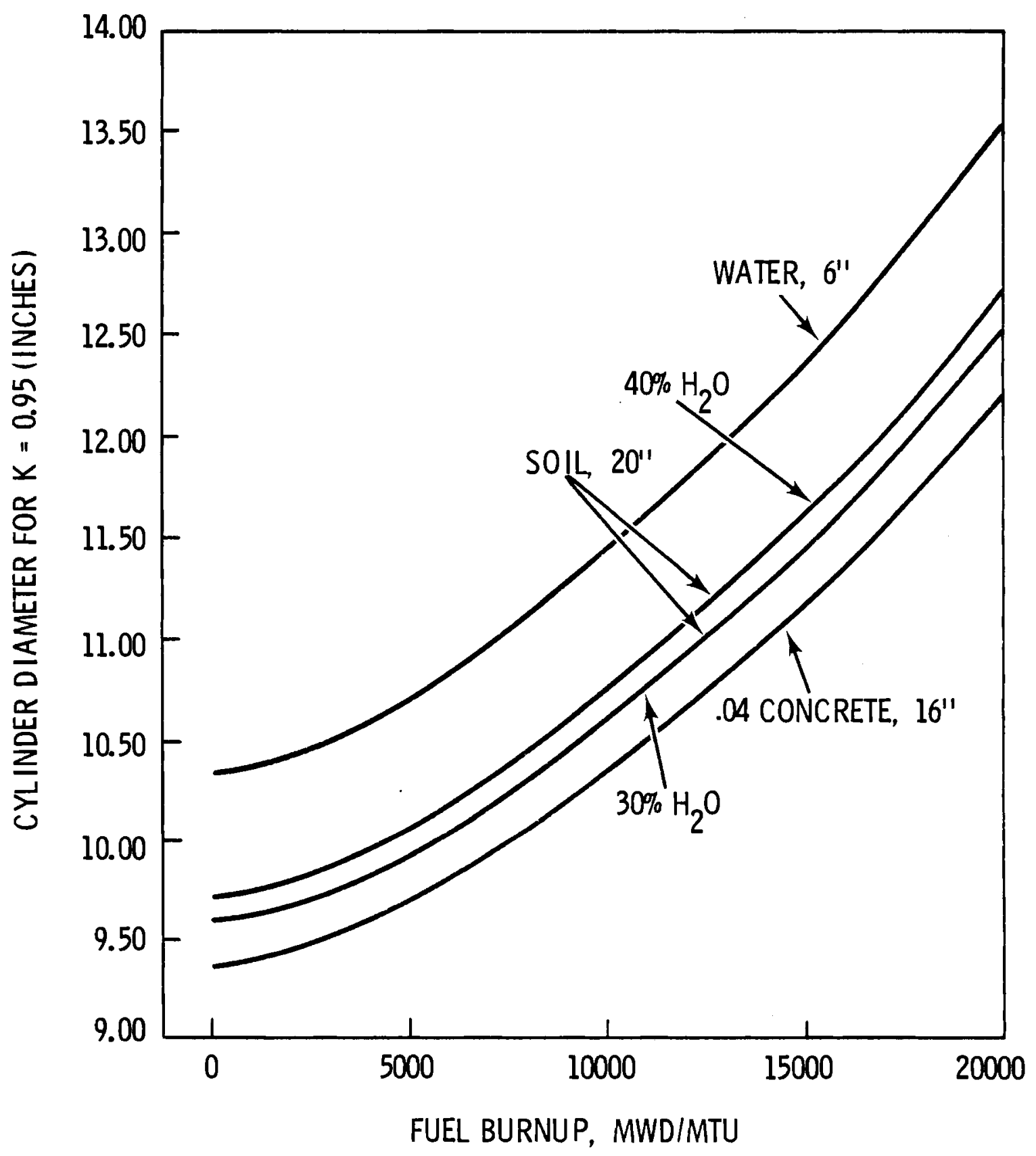

FIGURE 3. $\quad k_{\text {eff }}=0.95$ Cylinder Diameter with Disintegrated Fuel Solution 
to $k_{\text {eff }}=0.95$. The soil reflected cylinders need between 18,000 and 19,000 MWD/MTU for the reduction and for the concrete reflected cylinder 20,000 MWD/MTU or more is needed.

In drawing conclusions from this study, it is important to keep its limitations in mind. Credit for burnup has not been allowed in spent fuel storage facility licensing in reactor storage basins. Verification of exposure would be difficult. Fuel rod disintegration and optimum water mixtures are assumed. Only fissionable isotopes are included thereby neglecting the effect of neutron poisons in the spent fuel which would reduce its reactivity. Computer calculations for estimating isotopic concentrations are subject to error and calculations for reactivity do not have the verification support required for licensable quality.

Even with the reservations noted, it is apparent that taking credit for fissile isotope burnup does not completely remove the concern for criticality safety. It is possible that if liberal credit for burnup (including the effects of neutron poisons produced) was allowed a licensable design could be found. However, it is strongly recommended that alternative solutions to the criticality safety problem presented by rod disintegration be considered. There are several fronts on which the problem can be attacked. The first is the mechanism of disintegration itself. If the assemblies remain intact, the safety problem is considerably reduced.

Another area is water intrusion. If water entry into the disintegrated fuel can be avoided, then criticality would be prevented. If canister integrity cannot be adequately assured to licensing bodies, it is possible that use of a solid stabilizing medium could limit water intrusion to acceptable amounts.

The other items for possible safety improvement are canister shape, and a reduction of fuel material per canister. Changes of shape of the canister to increase the neutron leakage by increasing the surface of volume ratio would reduce reactivity. To be successful this might require the fuel assemblies to be dismantled. The most extreme solution would be to reduce the amount of fuel material to be stored in a canister. 
One additional method of criticality control is the inclusion of neutron poison material, such as boron, into the canister design. There exists however a potential requirement for periodic inspection to verify the presence of the poison. Such a system of inspections could result in a storage facility which does not meet the criterion for passive storage. Therefore additional poisons are not suggested as one of the possible solutions to the potential criticality safety problem. 


\section{REFERENCES}

1. S. W. Heaberlin and G. P. Selby, Criticality Safety Comparisons of Spent Fuel Facility Concepts. PNL-2590, Battelle, Pacific Northwest Laboratories, Richland, Washington, 1978.

2. M. J. Be11, ORIGEN - The ORNL Isotope Generation and Depletion Code. ORNL-4628, Oak Ridge Nationa T Laboratories, Oak Ridge, Tennessee, 1973.

3. C. R. Richey, EGGNIT: A Multigroup Cross-Section Code. BiNWL-1203, Battelle, Pacific Northwest Laboratories, Richland, Washington 99352 , November 1969.

4. J. R. Lilley, Computer Code HFN-Multigroup, Multiregion Neutron Diffusion Theory in One Space Dimension. HW-71545, General Electric, Hanford Atomic Products Operation, Richland, Washington, November 1961.

5. Reactor Physics Constants. 2nd Edition, ANL-5800, Argonne National Laboratory, July 1977.

6. K. R. Ridgway and R. D. Carter, Criticality Prevention Parameters of Plutonium in Soils. ARH-2622, Atlantic Richfield Hanford, Richland, Washington, October 1972. 
APPENDIX A

MATERIAL COMPOSITIONS ASSUMED IN REACTIVITY CALCULATIONS 
MATERIAL COMPOSITIONS ASSUMED IN REACTIVITY

CALCULATIONS NUMBER DENSITIES (atom/barn-cm)

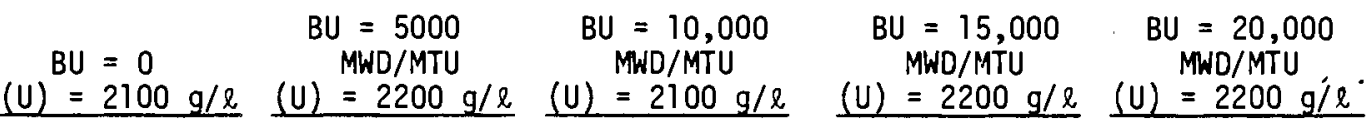

$\begin{array}{llllll}{ }^{235} \mathrm{U} & 1.897 \times 10^{-4} & 1.657 \times 10^{-4} & 1.324 \times 10^{-4} & 1.156 \times 10^{-4} & 9.471 \times 10^{-5} \\ 238 \mathrm{U} & 5.164 \times 10^{-3} & 5.394 \times 10^{-3} & 5.170 \times 10^{-3} & 5.433 \times 10^{-3} & 5.450 \times 10^{-3} \\ { }^{238} \mathrm{Pu} & & 6.465 \times 10^{-9} & 3.723 \times 10^{-8} & 1.133 \times 10^{-7} & 2.454 \times 10^{-7} \\ { }^{239} \mathrm{Pu} & & 1.241 \times 10^{-5} & 1.910 \times 10^{-5} & 2.481 \times 10^{-5} & 2.766 \times 10^{-5} \\ { }^{240} \mathrm{Pu} & & 9.590 \times 10^{-7} & 2.859 \times 10^{-6} & 5.381 \times 10^{-6} & 7.714 \times 10^{-6} \\ { }^{241} \mathrm{Pu} & & 9.684 \times 10^{-8} & 5.402 \times 10^{-7} & 1.449 \times 10^{-6} & 2.604 \times 10^{-6} \\ { }^{242} \mathrm{Pu} & & 3.498 \times 10^{-9} & 4.085 \times 10^{-8} & 1.734 \times 10^{-7} & 4.399 \times 10^{-7} \\ \mathrm{H} & 5.221 \times 10^{-2} & 5.160 \times 10^{-2} & 5.227 \times 10^{-2} & 5.155 \times 10^{-2} & 5.154 \times 10^{-2} \\ 0 & 3.681 \times 10^{-2} & 3.695 \times 10^{-2} & 3.678 \times 10^{-2} & 3.694 \times 10^{-2} & 3.694 \times 10^{-2} \\ \mathrm{H} / \text { in } & 9.7521 & 9.2584 & 9.8154 & 9.2381 & 9.2313\end{array}$

Note these values are not normalized to an initial concentration but rather given for an optimum concentration at that exposure. Some of the traditional trends, decreasing $238 \mathrm{U}$ for example, are not reflected in this type of presentation. 


\section{DISTRIBUTION}

No. of

Copies

OFFSITE

A. A. Churm

U.S. DOE Chicago Patent Group

Chicago Operations Office

9800 South Cass Avenue

Argonne, IL 60439

U.S. DOE Technical

Information Center

C. R. Cooley

U.S. Department of Energy, Headquarters

Washington, DC 20545

J. B. Work

U.S. Department of Energy, Headquarters

Washington, DC 20545

2 A. Roberts

U.S. Department of Energy, Nevada Operations Office P.0. Box 14100

Las Vegas, NV 89114

R. D. King

U.S. DOE Savannah River Operations Office

P.O. Box A

Aiken, SC 29801

F. L. Harris

Kaiser Engineers, Inc.

300 Lakeside Drive

Oakland, CA 94666

2 D. C. Durril

Westinghouse Electric Corp. Advanced Energy Systems

$$
\text { Division }
$$

P.0. Box 708

Mercury, NV 89023
No, of

Copies

ONSITE

2 J. B. Wright

Westinghouse Electric Corp.

Advanced Energy Systems

Division

P.0. Box 10864

Pittsburg, PA 15236

5 Hanford Engineering Development Laboratory

D. A. Cantley

J. F. Fletcher

R. L. Knecht

5 U.S. Department of Energy,

Richland Operations Office

W. E. Cawley

0. J. Elgert

P. G. Harris

F. L. Goldsberry

R. B. Goranson

H. E. Ransom

7 Rockwe 11 Hanford Operations

K. H. Henry

W. J. Kurzeka

D. A. Turner

D. D. Wodrich

Pacific Northwest Laboratory

2

I. S. Levy

R. C. Liikala

R. D. Widrig

L. D. Williams

R. E. Westerman

C. L. Brown

E. D. Clayton

G. P. Selby

S. W. Heaberl in

M. K. White

W. K. Winegardner

D. E. Larson

Technical Information

Publishing Coordination 